\title{
A new experimental tool to overcome a misconception concerning heat and internal energy
}

W.-B. Schneider et H. Dittmann

\section{(2) OpenEdition}

Journals

Édition électronique

URL : http://journals.openedition.org/trema/2366

DOI : $10.4000 /$ trema.2366

ISSN : 2107-0997

Éditeur

Faculté d'Éducation de l'université de Montpellier

Édition imprimée

Date de publication : 1 mai 1993

Pagination : 117-118

ISSN : 1167-315X

Référence électronique

W.-B. Schneider et H. Dittmann, «A new experimental tool to overcome a misconception concerning heat and internal energy », Tréma [En ligne], 3-4 | 1993, mis en ligne le 01 mai 1993, consulté le 19 avril 2019. URL : http://journals.openedition.org/trema/2366 ; DOI : 10.4000/trema.2366

Ce document a été généré automatiquement le 19 avril 2019

Trema 


\title{
A new experimental tool to overcome a misconception concerning heat and internal energy
}

\author{
W.-B. Schneider et H. Dittmann
}

1 The widespread misconception to make no difference between heat and internal energy is well known. From our experience this misconception has its origin in the lack of an adequate device to measure heat directly, i.e. to measure thermal energy in motion. It would be a similar situation if one teaches electricity without an ammeter as it had been about 150 years ago.

2 Normally, heat is measured by the change of internal energy through a change of temperature. This indirect method might be the origin of the students concept not to distinguish between heat and internal energy.

3 To overcome this difficulty we looked for a simple method to measure heat directly and to teach heat in a "correct way" even at school level.

4 We found small peltier moduls to be very well suited for this purpose [1]. These moduls normally are used to cool electronic devices and are available in ordinary electronic shops at a moderate price. We chose the model Melcor Cp 1.0-127-05L with 254 thermocouples which are connected in series electrically and parallel thermally [2].

5 The geometrical dimension of the modul is $30 \times 30 \times 3,2 \mathrm{~mm}$.

6 In a first application the peltier modul with its large number of thermocouples is well suited to detect small temperature differences. Experimentally we determined for the temperature region $0^{\circ} \mathrm{C}$ and $60^{\circ} \mathrm{C}$ the following relation between the voltage of the thermocouples $\mathrm{U}_{\text {th }}$ and the temperature difference $: \mathrm{Uth}=0.048 \mathrm{~V} / \mathrm{K} \Delta \mathrm{T}$. (1)

7 Equation 1 gives an idea of the sensitivity for small temperature differences, for example $1 \mathrm{mV}$ corresponds to $0.021 \mathrm{~K}$. Voltages in the region of $\mathrm{mV}$ can be directly measured with ordinary digital multimeter. 
8 A heat current $\mathrm{P}$ which traverses the surfaces of the peltier modul produces a small temperature difference corresponding to $\mathrm{P}$ which can be measured following equation 1 . Experimentally we obtained a linear relation between $\mathrm{U}_{\mathrm{th}}$ and $\mathrm{P}$ which allows the module to be used as the desired "heat meter" :

$$
\mathrm{U}_{\mathrm{th}}=0,086 \mathrm{~V} / \mathrm{W} \mathrm{P}(2)
$$

or with equation 1 :

$$
P=1,79 \mathrm{~W} / \mathrm{K} \Delta \mathrm{T}(3)
$$

The factor $1,79 \mathrm{~W} / \mathrm{K}$. stands for the thermal resistance of the heat meter. This resistance is not negligable small as necessary for an ideal heat meter. It is comparable to the thermal resistance of a rod of aluminium with the same surface as the peltier module and a length of about $30 \mathrm{~cm}$. But we found it small enough for most applications concerning teaching processes.

To illustrate an application of the so obtained heat meter we describe how to clarify the real meaning of the human temperature sense :

11 It is well known that a block of polystyrene gives a warmer sensation -when touching it than a block of iron although both blocks are at same temperature. Now we put the heat meter between the finger and the respective block. Surprisingly the heat meter indicates for polystyrene a much smaller heat current than for iron. This result indicates the human "temperature sense" to be in reality a sense for heat currents.

BIBLIOGRAPHIE

\section{References}

[1] : H. DITTMANN, W.B. SCHNEIDER : MNU (Zeitschrift für den mathematischnaturwissenschaftlichen Unterricht) 10, 1992.

[2] : MELCOR (Distributer in Germany : AMS Electronic GmbH, Albrechtstr. 14, D - 8000 München 19.

\section{RÉSUMÉS}

Nous présentons un dispositif expérimental permettant de faire comprendre aux étudiants la différence existant entre chaleur et énergie interne.

An experimental device is presented to overcome the difficulties encountered by students when studying heat and internal energy. 
INDEX

Mots-clés : chaleur, conception, dispositif expérimental, energie interne

\section{AUTEURS}

\section{W.-B. SCHNEIDER}

Physikalisches Institu - Didaktik der Physik, Universität Erlangen-Nürnberg, Germany

H. DITTMANN

Physikalisches Institu - Didaktik der Physik, Universität Erlangen-Nürnberg, Germany 